gPRYM

Gurnal Profesi Kesehatan Masyanakat

http://jurnal.bhmm.ac.id/index.php/jpkm

${ }^{\bowtie}$ Corresponding Author.

email address : edy.b@gmail.com

Received : 10 Januari 2021 Revised : 12 Februari 2021 Accepted : 11 April 2021

\title{
Hubungan Dukungan Keluarga dengan Tingkat Kesembuhan Penderita Tuberkulosis Paru di Wilayah Kerja Puskesmas Gantrung Kabupaten Madiun
}

\author{
Nita Nur Farida, ${ }^{\otimes}$ Edy Bachrun \\ Program Studi Kesehatan Masyarakat STIKES Bhakti Husada Mulia Madiun, Indonesia
}

\begin{abstract}
ABSTRAK
Penyakit Tuberculosis (TB) adalah infeksi menular yang disebabkan oleh bakteri Mycobacterium Tubercolusis dan penularannya dapat melalui udara (batuk, bersin, bicara atau tertawa). Di Indonesia pada tahun 2010didapatkan prevalensi TB paru sebesar 725 per 100.000 penduduk. Keberhasilan pengobatan TB sangat dipengaruhi oleh adanya dukungan dari keluarga. Berdasarkan studi pendahuluan yang telah dilakukan oleh peneliti, didapatkan hasil mulai tahun 2010-2014 penderita TB terbanyak berada di puskesmas Gantrung yaitu sebanyak 197 orang. Penelitian ini bertujuan untuk mengetahui hubungan dukungan keluarga dengan tingkat kesembuhan penderita Tuberkulosis paru.Jenis penelitian ini adalah analitik observasional, dengan desain Cross Sectional. Subjek penelitian ini adalah penderita TB paru di Puskesmas Gantrung yang terdiri 44 penderita diambil dengan teknik total sampling. Pengumpulan data menggunakan instrumen kuesioner. Analisis data menggunakan analisis univariat dan bivariat (dukungan keluarga dan tingkat kesembuhan) dengan uji Fisher Exact Test. Persentase penderita yang keluarganya mendukung sebesar 52,3\%, dan yang tidak mendukung sebesar 47,7\%. Persentase penderia yang sembuh sebesar 75\% dan yang gagal sebesar 25\%. Hasil uji Fisher didapatkan nilai P value =0,000 yakni lebih kecil dari 0,05 berarti terdapat hubungan $(O R=2,1 ; 95 \% C I=1,341$ - 3,289). Peningkatan peran serta keluarga tentang pengobatan TBC sangat diperlukan untuk mendapatkan hasil pengobatan yang optimal.
\end{abstract}

Kata kunci: Dukungan Keluarga, Tingkat Kesembuhan, Tuberkulosis

\section{PENDAHULUAN}

Penyakit Tubercolusis adalah infeksi menular yang disebabkan oleh bakteri Mycobacterium Tubercolusis. Tuberculosis adalah masalah kesehatan, baik dari sisi angka kematian (mortalitas), angka kejadian penyakit (morbiditas), maupun diagnosis dan terapinya. Sebagian besar kuman TB menyerang paru, tetapi dapat juga menyerang organ tubuh lainnya. Kuman TB menular dari orang ke orang melalui percikan dahak (droplet) ketika penderita TB paru aktif batuk, bersin, bicara atau tertawa. Kuman TB cepat mati dengan sinar matahari langsung, tetapi dapat bertahan hidup beberapa jam di tempat yang gelap dan lembab. Menurut Syam dkk. (2013), dalam jaringan tubuh kuman ini dapat tertidur lama (domant) selama beberapa tahun.
Berdasarkan Global Report Badan Kesehatan Dunia (WHO) tahun 2010, jumlah penderita TB paru di dunia sebanyak 14,4 juta kasus. Penderita TB paru terbanyak terdapat pada lima negara, yaitu : India, Cina, Afrika Selatan, Nigeria dan Indonesia. Pada tahun 2010 didapatkan prevalensi TB paru berdasarkan diagnosis sebesar 725 per 100.000 penduduk di Indonesia. Di negara-negara miskin, tingkat kematian akibat penyakit TB atau case fatality rate (CFR) sebesar 25\% dari seluruh jumlah kematian. Wilayah Asia Tenggara menanggung bagian terberat TB paru global yakni sekitar $38 \%$ dari kasus TB paru dunia. Penyakit TB paru merupakan penyebab kematian ketiga terbesar setelah penyakit kardiovaskuler dan penyakit saluran pernafasan dan merupakan nomor satu terbesar penyebab kematian dalam

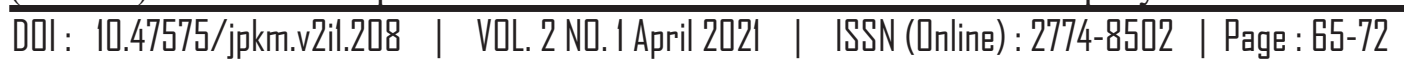


kelompok penyakit infeksi (Sufatmi, 2014).

Berdasarkan Data Dinkes Jatim tahun 2012, terdapat 41.440 penderita penyakit TB. Sedangkan tahun 2014 mengalami peningkatan menjadi 43.725 penderita TBC. Jumlah tersebut menyebabkan Jatim menempati peringkat 2 penderita TB di seluruh Indonesia setelah Jawa Tengah (Nurhantanto, 2014).

Berdasarkan studi pendahuluan yang telah dilakukan di Dinas Kesehatan Kabupaten Madiun, didapatkan hasil mulai tahun 20102014 penderita TB terbanyak berada di puskesmas Gantrung yaitu sebanyak 197 orang. Sesuai data di Puskesmas Gantrung, pada tahun 2013 terdapat 1 penderita TB yang gagal dalam pengobatan, 2 penderita yang meninggal dunia saat pengobatan berlangsung dan 41 dinyatakan sembuh dari TB.

Berdasarkan laporan hasil survei yang dilakukan oleh WHO dari tahun 2008 sampai dengan 2012 di negara-negara di dunia, bahwa penggunaan DOTS dan strategi stop TB mampu menurunkan beban TB setiap tahunnya (Media, 2011). Menurut Nizar (2010), menyatakan bahwa, dengan menggunakan strategi DOTS, maka proses penyembuhan TB paru dapat berlangsung secara cepat. Kategori kesembuhan penyakit TB yaitu suatu kondisi dimana individu telah menunjukan peningkatan kesehatan dan memiliki salah satu indikator kesembuhan penyakit TBC, diantaranya: menyelesaikan pengobatan secara lengkap dan pemeriksaan ulang dahak (follow up) hasilnya negatif pada akhir pengobatan dan minimal satu pemeriksaan folow up sebelumnya negatif (Muniroh, 2013).

Menurut Hendrik L. Blum derajat kesehatan masyarakat dipengaruhi oleh empat faktor yaitu, Lingkungan, Perilaku, Pelayanan Kesehatan dan Keturunan. Dari keempat faktor tersebut menurut Blum faktor lingkungan dan perilaku adalah faktor yang paling besar mempengaruhi derajat kesehatan masyarakat (Putra, 2011).

Menurut Rachmawati \& Turniani (2006), menyatakan bahwa TB Paru dapat sembuh bila dilakukan pengobatan secara teratur selama 6-8 bulan. Karena pengobatan memerlukan waktu yang lama maka penderita TB Paru sangat memungkinkan mengalami stress yang cukup berat sehingga selain diperlukan pengobatan secara medis juga diperlukan dukungan sosial dari keluarga maupun orang di sekitarnya (Syam, 2013).

Menurut Zahara (2007), menemukan bahwa dukungan keluarga merupakan faktor penting keberhasilan pasien TB dalam mematuhi program pengobatan. Seseorang dengan dukungan keluarga kurang memiliki peluang tidak patuh minum obat 5-6 kali (Septia, 2013).

Tujuan penelitian adalah untuk mengetahui apakah terdapat hubungan dukungan keluarga dengan tingkat kesembuhan dari penderita Tuberkulosis Paru di wilayah kerja Puskesmas Gantrung Kabupaten Madiun.

\section{METODE PENELITIAN}

Penelitian ini merupakan jenis penelitian analitik observasional, yang bertujuan untuk menganalisis kausa atau determinan dari suatu fenomena. Pada penelitian ini peneliti menggunakan pendekatan Cross Sectional (potong lintang), adalah rancangan penelitian yang mencangkup semua jenis penelitian yang pengukuran variabel-variabel dilakukan hanya 1 kali, pada 1 saat. Penelitian Cross Sectional bertujuan untuk menganalisis hubugan antara variabel bebas (dukungan keluarga) dan variabel terikat (tingkat kesembuhan penderita TBC).

Populasi pada penelitian ini adalah penderita TB Paru yang telah menjalani pengobatan di Puskesmas Gantrung yaitu sebanyak 44 orang. Pengambilan jumlah sampel dengan teknik total sampling. Sehingga dalam penelitian ini sampel yang digunakan adalah 44 orang di Puskesmas Gantrung. Intrumen penelitian ini menggunakan kuesioner tertutup dan observasi. Uji analisa data menggunakan uji Fisher Exact Test.

\section{HASIL DAN PEMBAHASAN}

Puskesmas Gantrung merupakan Puskesmas PONED (Pelayanan Obstetri Neonatus Essensial Dasar) yang buka 24 jam untuk penangan kegawatdaruratan obstetri dan neonatal dasar. Di Puskesmas Gantrung sudah terdapat juga koordinator penyakit menular khususnya penyakit TBC yaitu $\mathrm{Bu}$ Atik Setiarsih, Amd.Kep. 
Karakteristik Penderita TBC di Puskesmas Gantrung

Karakteristik penderita TBC yang diamati berdasarkan umur, jenis pekerjaan dan pendidikan.

Tabel 1

Karakteristik Penderita TBC Berdasarkan Umur di Wilayah Kerja Puskesmas Gantrung Bulan Juni Tahun 2016

\begin{tabular}{lccc}
\hline No & Umur & Jumlah & Persentase (\%) \\
\hline 1. & $19-29$ & 5 & 11,4 \\
2. & $30-40$ & 5 & 11,4 \\
3. & $41-51$ & 5 & 11,4 \\
4. & $52-62$ & 12 & 27,3 \\
5. & $63-73$ & 9 & 20,5 \\
6. & $74-84$ & 8 & 18,2 \\
Total & & 44 & 100 \\
\hline
\end{tabular}

Sumber: Data Primer, 2016

Berdasarakan tabel 1, diatas dapat diketahui jumlah penderita terbanyak adalah dengan rentang umur 52-62 tahun sebanyak 12 orang $(27,3 \%)$ sedangkan jumlah terendah adalah dengan rentang umur 19-29, 30-40 dan 41-51 tahun sebanyak 5 orang $(11,4 \%)$.

Tabel 2

Karakteristik Penderita TBC Berdasarkan Jenis Pekerjaan di Wilayah Kerja Puskesmas Gantrung Bulan Juni Tahun 2016

\begin{tabular}{llcc}
\hline No & $\begin{array}{l}\text { Jenis } \\
\text { Pekerjaan }\end{array}$ & Jumlah & $\begin{array}{c}\text { Persentase } \\
(\%)\end{array}$ \\
\hline 1. & Tani/Buruh Tani & 26 & 59,1 \\
2. & Swasta & 1 & 2.3 \\
3. & Wiraswasta & 9 & 20,5 \\
4. & Ibu Rumah & 7 & 15,9 \\
& Tangga & & \\
5. & Pelajar & 1 & 2.3 \\
Total & & 44 & 100 \\
\hline
\end{tabular}

Sumber: Data Primer, 2016

Berdasarakan tabel 2, dapat diketahui bahwa sebagaian besar penderita pekerjaannya adalah sebagai tani/buruh tani sebanyak 26 orang $(59,1 \%)$ dan yang paling rendah adalah pekerja swasta dan pelajar yaitu 1 orang $(2,3 \%)$.

Berdasarakan tabel 3, dapat diketahui bahwa yang paling tinggi pendidikan terakhirnya adalah pendidikan dasar sebanyak
20 orang $(45,5 \%)$ dan yang rendah adalah pendidikan menengah sebanyak 10 orang $(22,7 \%)$.

Tabel 3

Karakteristik Penderita TBC Berdasarkan Pendidikan Terakhir di Wilayah Kerja Puskesmas Gantrung Bulan Juni Tahun 2016

\begin{tabular}{llcc}
\hline No & $\begin{array}{l}\text { Pendidikan } \\
\text { Terakhir }\end{array}$ & Jumlah & $\begin{array}{c}\text { Persentase } \\
(\%)\end{array}$ \\
\hline 1. & $\begin{array}{l}\text { Pendidikan Dasar } \\
\text { (SD, SMP) }\end{array}$ & 34 & 77,3 \\
2. & $\begin{array}{l}\text { Pendidikan } \\
\text { Menengah (SMA) }\end{array}$ & 10 & 22,7 \\
Total & & 44 & 100 \\
\hline
\end{tabular}

Sumber: Data Primer, 2016

\section{Dukungan Keluarga pada Penderita TBC di} Puskesmas Gantrung

Berdasarakan tabel 4, dapat diketahui bahwa sebagian besar penderita keluarganya mendukung yaitu sebanyak 23 orang (52,3 $\%)$ dan terendah adalah yang tidak didukung keluarga sebanyak 21 orang $(47,7 \%)$.

Tabel 4

Distribusi Penderita TBC Berdasarkan

Dukungan Keluarga di Wilayah Kerja Puskesmas Gantrung Bulan Juni Tahun 2016

\begin{tabular}{llcc}
\hline No & $\begin{array}{l}\text { Dukungan } \\
\text { Keluarga }\end{array}$ & Jumlah & $\begin{array}{c}\text { Persentase } \\
(\%)\end{array}$ \\
\hline 1. & Mendukung & 23 & 52,3 \\
2. & Tidak Mendukung & 21 & 47,7 \\
Total & 44 & 100 \\
\hline
\end{tabular}

Sumber: Data Primer, 2016

Tingkat Kesembuhan pada Penderita TBC di Puskesmas Gantrung

Berdasarakan tabel 5, dapat diketahui bahwa jumlah penderita terbanyak adalah yang sembuh sebanyak 33 orang $(75,0 \%)$ dan terendah adalah yang gagal sebanyak 11 orang $(25,0 \%)$.

Tabel 6, menunjukkan bahwa responden yang didukung oleh keluarga sebanyak 23 orang (52,3 $\%)$ dengan rincian yang mengalami kesembuhan sebanyak 23 orang $(52,3 \%)$ dan yang gagal tidak ada $(0 \%)$, sedangkan yang tidak didukung oleh keluarga sebanyak 21 orang $(47,7 \%)$ dengan rincian yang mengalami kesembuhan sebanyak 10 orang $(22,7 \%)$ dan yang gagal 11 orang $(25,0 \%)$. 
Tabel 5

Distribusi Penderita TBC Berdasarkan

Tingkat Kesembuhan di Wilayah Kerja Puskesmas Gantrung Bulan Juni Tahun 2016

\begin{tabular}{llcc}
\hline No & $\begin{array}{l}\text { Tingkat } \\
\text { Kesembuhan }\end{array}$ & Jumlah & $\begin{array}{c}\text { Persentase } \\
(\%)\end{array}$ \\
\hline 1. Sembuh & 33 & 75,0 \\
2. Gagal & 11 & 25,0 \\
\multicolumn{2}{l}{ Total } & 44 & 100 \\
\hline
\end{tabular}

Sumber: Data Primer, 2016

Berdasarkan analisis uji Chi-Square pada tabel terdapat cell dengan nilai frekuensi kenyataan sebesar 0 (nol), hal ini tidak memenuhi syarat uji Chi-Square. Uji alternatif yaituuji Fisher menghasilkan nilai $\mathrm{P}_{\text {value }}=$ 0,000. Dengan demikian menunjukkan bahwa $\mathrm{P}_{\text {Value }}<\alpha$, dengan demikian $\mathrm{H}_{0}$ ditolak dan $\mathrm{H}_{1}$ diterima. Hal ini berarti terdapat hubungan antara dukungan keluarga dengan tingkat kesembuhan penderita TBC.

Odds Ratio adalah perhitungan untuk mengetahui seberapa besar ukuran kekuatan hubungan atau risk estimate antara variabel dukungan keluarga dengan tingkat kesembuhan penderita TBC, perhitungan OR menghasilkan nilai 2,1 OR $>1$ artinya mempertinggi hubungan sehingga dapat disimpulkan bahwa pasien TB paru yang didukung oleh keluarganya dalam pengobatan memiliki kemungkinan untuk sembuh 2 kali lebih besar daripada yang tidak mendapat dukungan dari keluarga. Interval kepercayaan (CI) batas bawah 1,341 dan batas atas 3,289 (batas atas dan bawah $>1$ maka memperkuat dugaan) sehingga dikatakan bahwa makin kuat dugaan jika dukungan keluarga berhubungan dengan tingkat kesembuhan penderita TBC.

\section{Pembahasan}

\section{Dukungan Keluarga}

Hasil analisis menunjukkan bahwa sebagian besar keluarga memberikan dukungan kepada penderita TB paru di Puskesmas Gantrung sebesar 52,3 \% dan yang terendah adalah keluarga yang tidak memberikan dukungan kepada penderita TB paru di Puskesmas Gantrung sebesar $47,7 \%$.

Menurut Friedman (1998), dukungan keluarga mengacu kepada dukungan-dukungan yang dipandang oleh anggota keluarga sebagai suatu yang dapat diakses/diadakan untuk keluarga (dukungan bisa digunakan atau tidak digunakan, tapi anggota keluarga memandang bahwa orang yang bersifat mendukung selalu siap memberikan pertolongan dan bantuan jika diperlukan) (Ulfah, 2011).

Hasil analisis menunjukkan bahwa keluarga mendukung pengobatan yang dilakukan oleh penderita TB paru. Hal ini dapat diartikan sebagai bentuk sikap, tindakan maupun penerimaan keluarga terhadap penderita TB paru telah dilakukan dengan baik. Dukungan yang utama diberikan kepada penderita TB paru yaitu pendampingan pada masa pengobatan.

Dan yang kurang memberikan dukungan kepada penderita TB paru di Puskesmas Gantrung disebabkan oleh anggota keluarga yang bekerja jauh sehingga waktu untuk berkumpul sangat singkat. Rata-rata penderita beranggapan jika keluarganya tidak peduli dengan penyakit dan kesembuhannya karena keluarganya sibuk dengan urusan serta pekerjaannya. Sehingga tidak ada yang mengingatkan dia makan ataupun meminum obat secara rutin dan jarang mendapatkan informasi mengenai bahaya jika tidak meminum obat secara teratur.

Tabel 6

Analisis Hubungan Dukungan Keluarga dengan Tingkat Kesembuhan Penderita TBC di Wilayah Kerja Puskesmas Gantrung Bulan Juni Tahun 2016

\begin{tabular}{|c|c|c|c|c|c|c|c|c|}
\hline \multirow{3}{*}{ Dukungan Keluarga } & \multicolumn{4}{|c|}{ Kesembuhan } & \multirow{3}{*}{ Total } & \multirow{3}{*}{$\%$} & \multirow{3}{*}{$\begin{array}{c}\text { OR } \\
95 \%\end{array}$} & \multirow{3}{*}{$\begin{array}{c}\mathrm{P} \\
\text { Value }\end{array}$} \\
\hline & \multicolumn{2}{|c|}{ Sembuh } & \multicolumn{2}{|c|}{ Gagal } & & & & \\
\hline & $\mathrm{N}$ & $\%$ & $\mathrm{~N}$ & $\%$ & & & & \\
\hline Mendukung & 23 & 52,3 & 0 & 0 & 23 & 52,3 & 2,100 & \\
\hline Tidak Mendukung & 10 & 22,7 & 11 & 25 & 21 & 47,7 & $1,341-$ & 0,000 \\
\hline Total & 33 & 75,0 & 11 & 25 & 44 & 100 & 3,289 & \\
\hline
\end{tabular}

Sumber: Data Primer, 2016 


\section{Tingkat Kesembuhan}

Hasil analisis data menunjukkan sebagian besar penderita TB paru di Puskesmas Gantrung adalah yang mengalami kesembuhan yaitu sebesar $75 \%$ dan yang terendah adalah yang mengalami kegagalan yaitu sebanyak $25 \%$.

Obat Tuberkulosis diberikan dalam bentuk kombinasi dari berbagai jenis, dalam jumlah yang cukup dan dosis tepat selama 6-8 bulan, supaya semua kuman mati (termasuk kuman persisten). Dosis tahap intensif dan dosis tahap lanjutan ditelan sebagai dosis tunggal. Pada tahap intensif, penderita mendapat obat setiap hari dan diawasi langsung untuk mencegah terjadinya kekebalan terhadap semua OAT (Obat Anti TBC), bila pengobatan tahap intensif ini diberikan secara tepat, biasanya penderita menular jadi tidak menular dalam kurun waktu 2 minggu, sebagian besar penderita Tuberkulosis BTA positif akan menjadi BTA negatif pada akhir pengobatan intensif. Tahap lanjutan, penderita mendapat jenis obat lebih sedikit, namun dalam jangka waktu yang lebih lama, sebab dapat juga untuk membunuh kuman persisten (dormant) sehingga dapat mencegah terjadinya kekambuhan (Kemenkes RI, 2011).

Hasil penelitian ini menunjukkan penderita TB paru yang mengalami kesembuhan mempunyai komitmen yang tinggi untuk melakukan pengobatan dengan disiplin. Komitmen penderita dalam melakukan pengobatan merupakan faktor penting dalam keberhasilan kesembuhan diluar berbagai faktor lain yang mempengaruhi tingkat kesembuhan.

Penderita yang mengalami kegagalan dalam pengobatan disebabkan oleh kurangnya motivasi penderita untuk sembuh dan dukungan keluarga yang sangat minim. Faktor pendidikan juga dapat mempengaruhi tingkat kesembuhan dari penderita TBC. Budioro B. tahun 2002 menjelaskan bahwa tingkat pendidikan dianggap sebagai salah satu unsur yang ikut menentukan pengalaman dan pengetahuan seseorang, baik dalam ilmu pengetahuan maupun dalam kehidupan sosial (Kholifah, 2009).

Dalam penelitian ini sebagian besar penderita TBC adalah berpendidikan rendah (SD,SMP) sebanyak 45,5\%, sangat mungkin jika penderita $\mathrm{TBC}$ kurang mengetahui cara hidup bersih dan sehat baik untuk dirinya sendiri maupun orang di sekitarnya. Hal ini juga berpengaruh dalam pengobatan TB yang memerlukan waktu pengobatan panjang (lama) sehingga penderita jenuh dan tidak melanjutkan pengobatannya.

\section{Hubungan Dukungan Keluarga terhadap Tingkat Kesembuhan Penderita TB Paru di Puskesmas Gantrung}

Dari analisis yang dilakukan peneiti diperoleh hasil bahwa penderita TBC yang mendapatkan dukungan keluarga serta mengalami kesembuhan sebanyak 52,3\% dan tidak ada yang mengalami kegagalan dalam pengobatan. Tetapi penderita yang tidak mendapatkan dukungan dari keluarga dan mengalami kegagalan dalam pengobatan adalah sebanyak $25,0 \%$.

Berdasarkan analisis uji Chi-Square pada tabel terdapat cell dengan nilai frekuensi kenyataan sebesar 0 (nol), hal ini tidak memenuhi syarat uji Chi-Square. Uji alternatif yaituuji Fisher menghasilkan nilai $\mathrm{P}_{\text {value }}=$ 0,000 . Dengan demikian menunjukkan bahwa $\mathrm{P}_{\text {Value }}<\alpha$, dengan demikian $\mathrm{H}_{0}$ ditolak dan $\mathrm{H}_{1}$ diterima. Hal ini berarti terdapat hubungan antara dukungan keluarga dengan tingkat kesembuhan penderita TBC.

Hal ini diperkuat dengan perhitungan OR dan CI dari hasil uji SPSS 16.0 for Window. Hasil Odds Ratio sebesar 2 (berarti berada di OR $>1$ artinya mempertinggi hubungan) sehingga dapat disimpulkan bahwa pasien TB paru yang didukung oleh keluarganya dalam pengobatan memiliki kemungkinan untuk sembuh 2 kali lebih besar daripada yang tidak mendapat dukungan dari keluarga. Interval kepercayaan (CI) batas bawah 1,341 dan batas atas 3,289 (batas atas dan bawah $>1$ maka memperkuat dugaan) sehingga dikatakan bahwa makin kuat dugaan jika dukungan keluarga berhubungan dengan tingkat kesembuhan penderita TBC $\left(\mathrm{OR}=2,1[1,341-3,289] ; \mathrm{P}_{\mathrm{Value}}=0,000\right)$.

Keberhasilan kesembuhan penyakit TBC sangat tergantung dari kepatuhan penderita untuk minum obat, hal ini tentu saja tidak terlepas dari peran dukungan keluarga. Friedman (1998), berpendapat orang yang hidup dalam lingkungan yang bersifat suportif, kondisinya jauh lebih baik dari 
pada mereka yang tidak memiliki lingkungan suportif. Dukungan keluarga mengacu kepada dukungan-dukungan yang dipandang oleh anggota keluarga sebagai suatu yang dapat diakses/diadakan untuk keluarga (Ulfah, 2011). Menurut UU No.23 tahun 1992, keluarga sebagai unit terkecil dari masyarakat mempunyai nilai strategis dalam pembangunan kesehatan, karena setiap masalah individu merupakan masalah keluarga dan sebaliknya. Kesehatan keluarga meliputi kesehatan suami, isteri, anak, dan anggota keluarga lainnya (Eka, 2011).

Penelitian ini sesuai dengan penelitian yang dilakukan oleh Asra Septia, dkk (2013) dengan judul "Hubungan dukungan keluarga dengankepatuhan minum obat padapenderita TB paru". Analisa data didapatkan nilai p-value $=0.036$. Nilai p-value ini lebih kecil dari $(\alpha)=0.05$ menunjukkan bahwa terdapat hubungan antara dukungan keluarga dengan kapatuhan minum obat pada penderita TB Paru di Rumah Sakit Umum Daerah Arifin Achmad. Mayoritas penderita TB Paru pada penelitian ini tinggal bersama istri, sehingga banyak yang mendapatkan dukungan dari keluarga dan penderita patuh dalam meminum obat setiap harinya.

Berdasarkan penelitian yang dilakukan, peneliti berasumsi bahwa dukungan keluarga turut menyebabkan penderita mengalami kesembuhan dari penyakit TBC, karena dalam pengobatan TBC membutuhkan waktu yang panjang (6-8 bulan) dan di haruskan untuk mengkonsumsi Obat Anti TBC secara rutin supaya cepat mendapatkan kesembuhan. Peran keluarga sangat di butuhkan untuk mendampingi penderita agar tidak putus asa dalam menjalani pengobatan yang membutuhkan waktu lama, dan penderita juga mempunyai dorongan serta semangat untuk melakukan pengobatan demi mendapatkan kesembuhan.

Dalam penelitian ini, peneliti menemukan beberapa penderita yang kurang mendapatkan dukungan dari keluarga dan mengalami kegagalan dalam pengobatan. Hal ini terjadi karena penderita tidak mempunyai semangat untuk sembuh dan keluarga kurang memberikan motivasi serta dorongan kepada penderita untuk melanjutkan pengobatan hingga tuntas, sehingga untuk mencapai suatu kesembuhan sangat minim namun kemungkinan untuk gagal dalam pengobatan sangat tinggi. Kegagalan dalam pengobatan TB juga terjadi kemungkinan karena akibat dari pengobatan yang tidak adekuat sehingga kuman TBC akan berkembang menjadi kuman resisten (daya imun rendah). Sistem imun yang rendah tersebut dapat menyebabkan bakteri dormant aktif kembali. Sehingga pada akhir pengobatan tahap intensif BTA terlihat positif kembali. Kemungkinan hal ini juga dapat disebabkan karena dahak yang kurang banyak atau bakteri yang sedikit sehingga dalam pemeriksaan mikroskopis hasil tidak terlihat (negatif).

\section{SIMPULAN}

Berdasarkan hasil penelitian dan pembahasan, dapat disimpulkan bahwa, 1) Banyak pasien TBC yang mendapatkan dukungan dari keluarga, yaitu sebanyak 52,3\%. 2) Sebagian besar pasien TBC yaitu 75,0 \% mengalami kesembuhan. 3) Terdapat hubungan yang signifikan antara dukungan keluarga terhadap tingkat kesembuhan penderita $\mathrm{TBC}(\mathrm{OR}=2,1$; $\left.\mathrm{P}_{\text {Value }}=0,000\right)$. Pasien TBC yang mendapat dukungan dari keluarga memiliki kemungkinan untuk sembuh 2 kali lebih besar daripada yang tidak mendapat dukungan dari keluarga.

\section{DAFTAR PUSTAKA}

Eka, Arsita. 2011. Ilmu Kesehatan Masyarakat Untuk Kebidanan Holistik (Integrasi Community Oriented ke Family Oriented). Yogyakarta : Nuha Medika.

Fibriana, Presti Linda. 2011. Hubungan Antara Sikap dengan Perilaku Keluarga tentang Pencegahan Penyakit Menular Tuberkulosis. Tersedia dalam : http:// www.dianhusada.ac.id/jurnalimg/ jurper1-9-lin.pdf (diakses Jum'at, 12 Februari 2016 pukul 14.14).

Departemen Kesehatan. 2011. Pedoman Nasional Pengendalian Tuberkulosis. Jakarta : Depkes.

Kholifah, Nur. 2009. Analisis Faktor yang Berhubungan dengan Kesembuhan Penderita Tb Paru (Studi Kasus di BP4 Salatiga Tahun 2008). Tersedia dalam : http://lib.unnes.ac.id/4007/1/5600.pdf (diakses 25 Februari 2016). 
Kunoli J. Firdaus. 2012. Asuhan Keperawatan Penyakit Tropis. Jakarta : CV. Trans Info Media.

Maulidia, Fitri Desy. 2014. Hubungan antara Dukungan Keluarga dan Kepatuhan MinumObatPadaPenderita Tuberkulosis di Wilayah Ciputat Tahun 2014. Tersedia dalam : http://repository.uinjkt.ac.id/ dspace/bitstream/123456789/25510/1/ DESY\%20FITRI\%20MAULIDIA\%20 -\%20FKIK.pdf (diakses Rabu, 25 Februari 2016 pukul 14.20).

Media, Yulfira. 2011. Pengetahuan, Sikap Dan Perilaku Masyarakat Tentang Penyakit Tuberkulosis (Tb) Paru di Kecamatan Sungai Tarab, Kabupaten Tanah Datar Propinsi Sumatera Barat. Tersedia dalam: http://ejournal.litbang. depkes.go.id/index.php/mpk/article/ download/108/89 (diakses Minggu, 17 Januari 2016 pukul 15.30).

Mokhtar, Salwa Khairiah dkk. 2012. Tuberculosis in Malaysia: A Study on the Level of Societal Awareness and Stigma. Tersedia dalam : http://iosrjournals.org/ iosr-jhss/papers/voll-issue4/H0145964. $p d f ? i d=5616 \quad$ (diakses Minggu, 17 Januari 2016 pukul 15.28).

Muniroh, Nuha dkk. 2013. Faktor-Faktor Yang Berhubungan dengan Kesembuhan Penyakit Tuberculosis (Tbc) Paru di Wilayah Kerja Puskesmas Mangkang Semarang Barat. Tersedia dalam : http://jurnal.unimus.ac.id/index.php/ JKK/article/view/923/975 (diakses 12 Februari 2016).

Notoatmodjo, Soekidjo. 2012. Metodologi Penelitian Kesehatan. Jakarta : Rineka Cipta.

Nurhartanto, Sandhi. 2014. Jatim Peringkat Dua Tuberculosis Se-Indonesia. Tersedia dalam : http://www.enciety.co/ jatim-peringkat-dua-tuberculosis-seindonesia/ (diakses 18 Januari 2016).
Puri, Andita Nomi. 2010. Hubungan Kinerja Pengawas Minum Obat (Pmo) dengan Kesembuhan Pasien Tb Paru Kasus Baru Strategi Dots. Tersedia dalam: https://digilib.uns.ac.id/dokumen/ download/13213/Mjc4MTg=/ Hubungan-kinerja-pengawas-minumobat-pmo-dengan-kesembuhan-pasientb-paru-kasus-baru-strategi-dotsabstrak.pdf (diakses Sabtu, 28 Februari 2016 pukul 13.04).

Putra, Rianda N. 2011. Hubungan Perilaku dan Kondisi Sanitasi Rumah dengan Kejadian Tb Paru di Kota Solok Tahun 2011. Tersedia dalam : http://repository. unand.ac.id/16894/1/SKRIPSI_ LENGKAP_NIKO.pdf (diakses Kamis, 24 Februari 2016 pukul 05.53).

Putri dkk.2014.Hubungan TingkatKesembuhan Tuberkulosis Paru Dewasa dengan Pengobatan Metode Dots dan Non Dots di Rumah Sakit Haji Abdoel Madjid Batoe Kabupaten Batanghari Provinsi Jambi Tahun 2011. Tersedia dalam : http:// journal.uii.ac.id/index.php/JKKI/ article/view/3383/3032 (diakses Senin, 18 Januari 2016, pukul 05.03).

Rosjidi, Harun Cholik. 2013. Panduan Penyusunan Proposal dan Laporan Penelitian untuk Mahasiswa Kesehatan. Ponorogo.

Saryono. 2010. Metodologi Penelitian Kebidanan DIII, DIV, S1 dan S2. Yogyakarta : Nuha Medika.

Septia, Asra dkk. 2013. Hubungan Dukungan Keluarga dengan Kepatuhan Minum Obat pada Penderita Tb Paru. Tersedia dalam : http://jom.unri.ac.id/index. php/jompsik/article/viewfile/3399/3296 (diakses Senin, 18 Januari 2016 pukul 04.49). 
72 Nita N. Farida \& E. Bachrun, Hubungan Dukungan Keluarga dengan Tingkat Kesembuhan Penderita Tuberkulosis Paru

Sufatmi, Sity. 2014. Pengaruh Karakteristik Personal dan Dukungan Keluarga terhadap Kepatuhan Minum Obat pada Pasien Tuberkulosis Paru di Kota Tanjung Balai. http://repository.usu. ac.id/bitstream/123456789/41460/5/ Chapter\%20I.pdf. Diakses 24 Februari 2016.

Sugiyono. 2011. Metode Penelitian Kuantitatif, Kualitatif dan $R$ \& $D$. Bandung : Alfabeta.

Sujarweni, Wiratna. 2014. Metodologi Ulfah, Maria. 2011. Hubungan Dukungan Keluarga dengan Kepatuhan Minum Obat Pada Pasien Tuberkulosis (Tbc) di Wilayah Kerja Puskesmas Pamulang Kota Tangerang Selatan Tahun 2011. http://repository.uinjkt.ac.id/dspace/ bitstream/123456789/25594/1/ MARIA\%20ULFAH-FKIK.pdf. Diakses 25 Februari 2016

Widyanto, Candra dkk. 2013. Trend Disease "Trend Penyakit Saat Ini". Jakarta : CV. Trans Info Media. Penelitian Keperawatan. Yogyakarta : Gava Media.

Supardi, Sudibyo dkk. 2014. Metodologi Penelitian untuk Mahasiswa Farmasi. Jakarta : CV. Trans Info Media.

Syam, Suyuti. 2013. Dukungan Sosial Penderita Tuberculosis Paru di Wilayah Kerja Puskesmas Ajangale Kabupaten Bone Tahun 2013. http:// repository.unhas.ac.id/bitstream/ handle/123456789/5660/jurnal. pdf? sequence $=1$. Diakses 18 Januari 2016. 